\title{
MAQASHID SYARIAH INDEX DAN DEWAN KOMISARIS INDEPENDEN TERHADAP NILAI PERUSAHAN DENGAN PROFITABILITAS SEBAGAI VARIABEL MEDIASI PADA PERUSAHAAN ASURANSI SYARIAH
}

\author{
Puji Sahara1), Titin Hartini²), Sri Delasmi Jayanti3) \\ 123) Universitas Islam Negeri Raden Fatah, Palembang \\ Emai11.pujisahara23@gmail.com \\ Email² titinhartini_uin@radenfatah.ac.id \\ Email33sri_delasmi@yahoo.com
}

\begin{abstract}
This study aims to examine the effect of maqashid syariah index, an independent board of commissioners on firm value by mediating profitability. The population in this study is sharia insurance companies listed on the Indonesia Stock Exchange. The independent variable of this study is maqashid syariah index (X1) and independent board of commissioners (X2), while the mediating variable namely profitability $(Z)$, and the dependent variable of this study is the value of the company (Y). The method of this research uses quantitative research methods using secondary data. The sampling technique uses a purposive sample method and is based on predetermined criteria. From the sampling method applied, 11 insurance companies were listed on the Indonesia Stock Exchange (IDX) for the period of 2015 - 2018. Data analysis techniques used regression analysis and path analysis using SPSS 22. The results showed that the maqashid syariah index had an effect on profitability, the independent board of commissioners had no effect on profitability, the maqashid sharia index had no effect on firm value, the independent board of commissioners had an effect on company value, partial mediation had influence on maqashid index on firm value, profitability does not mediate the influence of the independent board of commissioners on the value of the company.
\end{abstract}

Keywords: maqashid syariah index, independent board of commissioners, company value, profitability

\section{PENDAHULUAN}

Pada dasarnya, sebuah perusahaan didirikan untuk mencapai tujuannya. Menurut Harjito dan Martono (2018), ada tiga tujuan, pertama untuk mencapai keuntungan yang maksimal, kedua untuk kemakmuran pemilik perusahaan dan para pemilik saham, dan ketiga adalah menciptakan nilai perusahaan. Penciptaan nilai perusahaan dilakukan dengan meninjau kinerja keuangan pada peningkatan nilai perusahaan yang diukur menggunakan PBV, yang mana tingkat nilai perusahaan yang tinggi akan membuat pasar percaya tidak hanya pada kinerja perusahaan saat ini, namun juga harapan perusahaan di masa mendatang.

Bursa Efek Indonesia (BEI) menunjukkan pertumbuhan industri keuangan syariah di Indonesia dengan membentuk produk asuransi mikro yang telah resmi diluncurkan pada 
Tahun 2014. Perkembangan jumlah nilai perusahaan ini dapat ditunjukkan pada Grafik 1 berikut ini:

\section{Gambar 1}

Perkembangan Nilai Perusahaan Asuransi Syariah 2015 - 2018

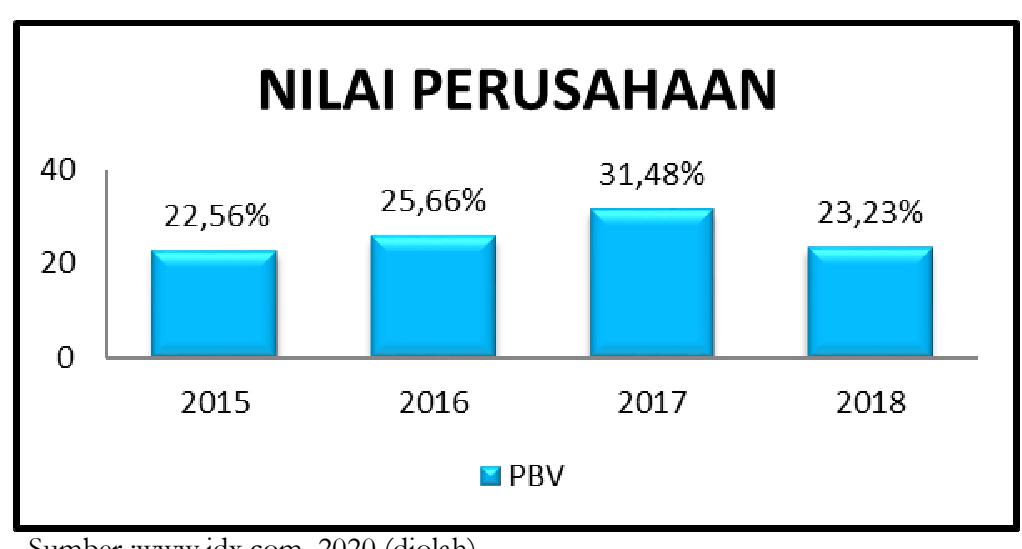

Sumber :www.idx.com. 2020 (diolah)

Berdasarkan Grafik 1 diatas, data nilai perusahaan (PBV) yang dirilis Bursa Efek Indonesia (BEI), menjelaskan bahwa perkembangan jumlah perusahaan perasuransian syariah meningkat dari Tahun 2015 - 2017 yang mencapai 22,56\%, pada Tahun 2018 indeks sektor perusahaan asuransi syariah mengalami penurun sebesar 8,25\% yang berdampak pada kurangnya minat investor untuk menanamkan modalnya sehingga perusahaan asuransi mengalami penurunan nilai perusahaan.

Dengan semakin meningkatnya posisi invetasi dan modal kerja serta bertambahnya jumlah perusahan asuransi pada ahun 2018. Pengukuran nilai perusahaan dengan kinerja perusahaan yang sesuai dengan prinsip syariah yang dirumuskan dengan maqashid syariah index sebagai pendekatan untuk mengukur kinerja keuangan perusahaan asuransi syariah agar sesuai dengan tujuannya. Maqashid syariah index (MSI) merupakan pengembangan dari penelitian sebelumnya yang dilakukan Antonio, Sanrego dan Taufik (2012) mengenai analisis kinerja mengunakan maqashid syariah index dengan kerangka maqashid syariah yang meliputi elemen pendidikan bagi individu, keadilan dan kepentingan masyarakat dengan 9 rasio yaitu hibah pendidikan, penelitian/pelaihan, publisitas, biaya yang terjangkau, fungsi distribusi, produk non bunga, rasio laba dan investasi disektor riil.

Adanya dewan komisaris independen digunakan untuk mengukur implementasi penerapan nilai perusahaan yang dikelola secara efisiensi sesuai dengan keinginan pemegang saham. Komie Nasional Kebijakan Governance (KNKG) menjelaskan bahwa dalam mendorong praktik bisnis syariah yang kuat dan sehat secara finansial dan senantiasa mengacu kepada prinsip-prinsp syariah, maka lembaga bisnis syariah diharapkan untuk melaksanakan prinsip-prinsip tata kelola perusahaan dengan dewan komisaris independen akan mendorong proses perusahaan yang lebih baik sehingga berdampak kondusif terhadap munculnya asuransi syariah, Semakin tinggi tingkat implementasi dewan komisaris independen menjadi salah satu faktor yang mempengaruhi nilai perusahaan asuransi syariah.

Investor juga pada umumnya juga memperhatikan kemampuan perusahaan dalam memperoleh keuntungan yang diukur dengan rasio profitabilitas. Profitabilitas merupakan suatu indikator kinerja yang dilakukan oleh manajemen perusahaan dalam mengelola kekayaan perusahaan yang ditunjukan oleh laba yang dihasilkan perusahaan dengan 
mengunakan indikator return on aset (ROA) yang mengambarkan sejauh mana aset perusahaan yang ditanamkan atau ditempatkan mampu memberikan pengembalian keuntungan sesuai dengan yang diharapkan (Irham Fahmi, 2015).

\section{KERANGKA TEORITIS DAN PENGEMBANGAN HIPOTESIS Teori Agency}

Menurut Brigham dan Houston teori ini merupakan tindakan yang diambil para manajer yang diberikan kekuasaan oleh pemilik perusahaan yaitu pemegang saham untuk membuat keputusan, dimana hal ini menciptakan potensi konflik kepentingan. Konsep teory agency didasari pada permasalahan agency yang muncul ketika pengurusan suatu perusahaan terpisah dari kepemilikan. Konflik antar kelompok atau agency problem merupakan konflik antara pemilik, karyawan dan manajernya perusahaan dimana ada kecendurangan manajer lebih mementingkan tujuan individu dari pada tujuan perusahaan (Dinnul Alfian Akbar \& Rika Lidyah, 2017). Sedangkan Benhart dan Rosenstein (1998) menyatakan suatu mekanisme yang dapat mengatasi masalah keagenan tersebut yaitu mekanisme dewan komisaris independen yang akanbermanfaat untuk mengawasi manajemen dalam laporan keuangan.

\section{Signalling Theory}

Menurut Eugenen, F.Brigham dan Joel,F. Houstom (2011) menyatakan bahwa investor menganggap perubahan dividen sebagai sinyal dari perkiraan pendapat manajemen perusahaan sehingga informasi menyatakan suatu hal yang penting bagi investor karena pada umumnya menyajikan catatan atau keterangan perusahaan baik masa lalu maupun saat ini bagi kelangsungan perusahaan dan efeknya bagi pengembangan perusahaan.

Suatu informasi yang akurat, tepat, lengkap dan relevan sangat diperlukan oleh investor di pasar modal dan dijadikan sebagai alat ukur untuk menganalisis dalam mengambil keputusan investasi. Informasi yang disebar luaskan dapat memberikan sinyal kepada investor dan masyarakat luas dalam mengambil keputusan investasi. Informasi tersebut berperan penting, karena memberikan pengaruh pada keputusan yang akan diambil oleh pihak luar dan jika pihak luar tidak memiliki informasi yang cukup dalam menilai suatu perusahaan,maka cenderung melindungi diri dan mencari titik aman dengan memberikan harga rendah untuk perusahaan (Zainal Arifin.,2005).

\section{Nilai Perusahaan}

Nilai perusahaan merupakan persepsi investor terhadap tingkat keberhasilan perusahaan yang terkait erat dengan harga saham. Nilai perusahaan yang dibentuk melalui indikator pasar saham, sangat dipengaruhi oleh peluang-peluang investasi. Pengeluaran investasi memberikan sinyal dari investasi kepada manajer tentang pertumbuhan perusahaan dimasa yang akan datang, sehingga meningkatkan harga saham sebagai indikator nilai perusahaan (Lidia Desiana, 2018).

Pada penelitian ini alat ukur yang digunakan untuk menghitung nilai perusahaan ialah price book value (PBV) yang merupakan salah satu rasio nilai perusahaan dalam pengambilan keputusan investasi, nilai buku merupakan ukuran stabil dan sederhana yang dapat dibandingkan dengan harga saham dan dapat dibandingkan antara perusahaan sejenis yang menunjukan tanda mahal atau murahnya suatu saham. 


\section{Maqashid Syariah Index}

Maqashid syariah merupakan maslahat yang sering dikenal juga dengan istilah hikmah atau tujuan ditiadakannya suatu hukum. Ukuran kinerja perusahaan dalam penelitian ini menggunakan ukuran kinerja yang maqashid syariah index yang merupakan model pengukuran kinerja yang dipakai baik perbankan syariah maupun keuangan. Dalam penelitian Antonio maqashid syariah index dikembangkan 3 faktor utama, yaitu: pendidikan,penciptaan keadilan dan pencapaian kesejahteraan yang mensyaratkan perusahaan untuk mampu merancang program pendidikan dan pelatihan dengan nilai moral sehingga mereka mampu meningkatkan kemampuan dan keahlian para karyawan. Dalam pengembangan pengukuran kinerja pencapaian maqashid syariah mengadopsi teori Abu Zahrah yaitu interview terhadap 12 pakar yang memahami masalah perbankan, fiqh ekonomi dan keuangan syariah di asia tenggah dan timur tenggah dengan dimensi dan rasio kinerja yang akan digunakan untuk mengukur maqashid syariah index pada perusahaan (Novia Aisah, 2016).

\section{Dewan Komisaris Independen}

Dewan komisaris independen merupakan dewan komisaris yang berasal dari luar perusahaan yang bertujuan untuk melakukan mekanisme pengawasan perusahaan agar berjalan secara efektif sesuai dengan peraturan perundang-undangan sehingga memiliki peranan penting dalam perusahaan terutama pelaksanaan tata kelola perusahaan atau good corporate governance yang memberikan petunjuk serta arahan kepada pengelola perusahaan (management) selain itu komisaris independen dapat bertindak sebagai pencegah dalam perselisihan yang terjadi diantara para manajer dalam mengawasi kebijakan manajemen serta memberikan nasihat kepada manajemen. Alat ukur rasio dewan komisaris independen terhadap anggota dewan komisaris independen.

\section{Profitabilitas}

Profitabilitas merupakan kemampuan suatu perusahaan untuk mendapatkan laba (keuntungan) dalam suatu proses melalui semua kemampuan dan sumber daya yang ada seperti kegiataan penjualan, kas, modal jumlah karyawan dan sebagainya sejauh mana perusahaan menghasilkan laba dari penjualan dan investasi perusahaan. Rasio yang digunakan adalah return on aset (ROA) untuk mengukur keuntungan bersih yang diperoleh dari penggunaan aktiva (Sofyan Syafri Harapah, 2006).

Peningkatan daya tarik perusahaan menjadikan perusahaan tersebut semakin diminati investor, karena tingkat pengembalian akan semakin besar. Hal ini juga berdampak bahwa harga saham dari perusahaan tersebut di pasar modal juga akan semakin meningkat sehingga ROA akan berpengaruh terhadap harga saham perusahaan. return on aset mencerminkan seberapa besar return yang dihasilkan atas setiap rupiah uang yang ditanam dalam bentuk aset (Wenner R. Murhadi, 2013)

\section{Kerangka Pemikiran}

Berdasarkan pemaparan latar belakang dan tinjauan pustaka di atas, maka perumusan hipotesis dapat di tunjukan dalam kerangka pemikiran seperti yang ditunjukkan pada Gambar 2 berikut ini: 


\section{Gambar 2}

\section{Kerangka Pemikiran Penelitian}

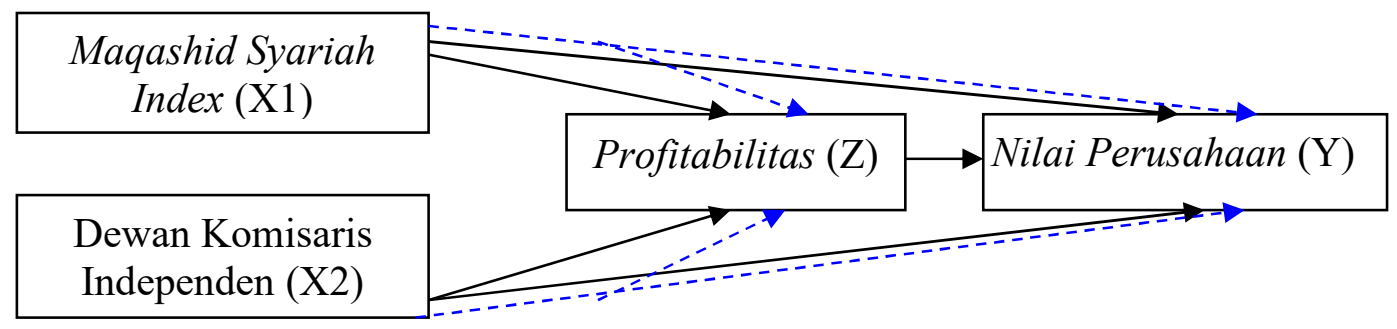

\section{Pengaruh Maqasid Syariah Index terhadap Profitabilitas}

Penelitian yang dilakukan oleh Vinus Maulina, Novia Kustyaningsih (2018) menunjukkan bahwa Indeks Maqashid berpengaruh terhadap profitabilitas yang berarti bahwa perusahaan menjalankan indeks maqashid maka profitabilitas perusahaan akan meningkat. Hal ini dikarenakan adanya rasio laba yang mendukung profitabilitas perusahaan. adanya laba yang dihasilkan akan berdampak positif terhadap investor. yang berarti bahwa ketika perusahaan akan menjalankan indeks maqashid syariah maka profitabilitas akan meningkat. Hal ini dikarenakan perusahaan dituntun untuk menciptakan maqashid syariah index melalui PER yang mana semakin tinggi cadangan 1 - PER maka semakin tinggi pula perusahaan dalam menciptakan index maqashid syariah.

H1 : Maqashid syariah index berpengaruh terhadap profitabilitas

\section{Pengaruh Dewan Komisaris Independen terhadap Profitabilitas}

Penelitian Fajrina Narjees Zahra (2016) yang membuktikan adanya dewan komisaris independen berpengaruh terhadap profitabilitas menunjukkan bahwa ketika DKI meningkat maka profitabilitas juga akan meningkat. Hal ini mendukung pernyataan Azhar Maksum bahwa dengan penerapan dewan komisaris independen maka proses pengambilan keputusan akan berlangsung secara lebih baik sehingga akan menghasilkan keputusan yang optimal, dapat meningkatkan efisiensi serta terciptanya budaya kerja yang sehat.

H2 : Dewan komisaris independen berpengaruh terhadap profitabilitas

\section{Pengaruh Maqashid Syariah Index terhadap Nilai Perusahaan}

Lindayani dalam penelitian Alfina Rosa Damayanti (2018) meneliti kinerja keuangan melalui maqashid syariah index dengan data yang diolah mengunakan SPSS 23 hasil simultan berpengaruh terhadap nilai perusahaan yang menunjukkan bahwa perusahaan memperhatikan tujuan syariah untuk menarik investor dan orientasi masa depan. Suhairi Harefa (2018) menyatakan bahwa jika pertumbuhan penjualan konsisten dan relatif stabil mencerminkan bahwa perusahaan dapat konsisten dalam meningkatkan dan mempertahankan kinerja maqashid syariah terhadap nilai perusahaan pada perusahaan subsektor makanan dan minuman dalam ISSI.

H3 : Maqashid syariab index berpengaruh terhadap nilai perusahaan 


\section{Pengaruh Dewan Komisaris Independen terhadap Nilai Perusahaan}

Penelitian Laurensia Chintia Dewi, Yeterina Widi (2014) yang membuktikan bahwa terdapat pengaruh dewan komisaris independen terhadap nilai perusahaan, pemantauan yang efektif terhadap manajemen yang dilakukan oleh dewan komisaris independen dan akuntabilitas dewan komisaris terhadap perusahaan dan pemegang saham akan dapat membantu meminimalkan agency conflict yang akhirnya akan berdampak pada peningkatan nilai perusahaan. hasil tersebut menyatakan bahwa komisaris independen memegang kendali dalam mengarahkan perusahaan untuk menjalankan operasionalnya sesuai standar yang telah ditentukan sehingga tujuan perusahaan dapat tercapai dengan baik.

H4 : Dewan komisaris independen berpengaruh terhadap nilai perusahaan

\section{Pengaruh Profitabilitas terhadap Nilai Perusahaan}

Penelitian Dea Putri ayu, A.A Gede Suarjaya (2017) profitabilitas berpengaruh terhadap nilai perusahaan yang artinya semakin tinggi profitabilitas yang diperoleh perusahaan, maka nilai perusahaan semakin meningkat. Hasil penelitian ini sesuai dengan perspektif teori sinyal yang menjelaskan bahwa peningkatan profitabilitas yang tercantum dalam laporan keuangan merupakan upaya dalam memberikan sinyal kepada investor berkaitan dengan kinerja perusahaan dan pertumbuhan prospek usaha dimasa mendatang. Upaya tersebut dapat membangun sentimen dari investor sehingga berpengaruh terhadap kenaikan harga saham di pasar modal. Peningkatan harga saham dapat meningkatkan nilai perusahaan dimata investor.

H5 : Profitabilitas berpengaruh terhadap nilai perusahaan

\section{Pengaruh Mediasi Profitabilitas terhadap Hubungan Maqashid Syariah Index dan Nilai Perusahaan}

Penelitian yang dilakukan oleh Vinus Maulina, Novia Kustyaningsih (2018) menunjukkan bahwa Indeks Maqashid perpengaruh terhadap profitabilitas yang berarti bahwa perusahaan menjalankan indeks maqashid maka profitabilitas perusahaan akan meningkat. Hal ini dikarenakan adanya rasio laba yang mendukung profitabilitas perusahaan. adanya laba yang dihasilkan akan berdampak positif terhadap investor. yang berarti bahwa ketika perusahaan akan menjalankan indeks maqashid syariah maka profitabilitas akan meningkat.

Penelitian Dea Putri ayu, A.A Gede Suarjaya (2017) profitabilitas berpengaruh terhadap nilai perusahaan yang artinya semakin tinggi profitabilitas yang diperoleh perusahaan, maka nilai perusahaan semakin meningkat.

H6 : Maqashid syariah index berpengaruh terhadap nilai perusahaan dengan di mediasi profitabilitas

\section{Pengaruh Mediasi Profitabilitas terhadap Hubungan Dewan Komisaris Independen terhadap Nilai Perusahaan}

Penelitian Fajrina Narjees Zahra (2017) yang membuktikan adanya dewan komisaris independen berpengaruh terhadap profitabilitas menunjukkan bahwa ketika DKI meningkat maka profitabilitas juga akan meningkat. Hal ini mendukung pernyataan Azhar Maksum bahwa dengan penerapan dewan komisaris independen maka proses pengambilan keputusan akan berlangsung secara lebih baik sehingga akan menghasilkan keputusan yang optimal, dapat meningkatkan efisiensi serta terciptanya budaya kerja yang sehat. 
Penelitian Dea Putri ayu, A.A Gede Suarjaya (2017) profitabilitas berpengaruh terhadap nilai perusahaan yang artinya semakin tinggi profitabilitas yang diperoleh perusahaan, maka nilai perusahaan semakin meningkat. Hasil penelitian ini sesuai dengan perspektif teori sinyal yang menjelaskan bahwa peningkatan profitabilitas yang tercantum dalam laporan keuangan merupakan upaya dalam memberikan sinyal kepada investor berkaitan dengan kinerja perusahaan dan pertumbuhan prospek usaha dimasa mendatang.

H7 : Dewan komisaris independen berpengaruh terhadap nilai perusahaan dengan dimediasi profitabilitas

\section{METODE PENELITIAN}

Desain Penelitian

Jenis penelitian yang digunakan dalam penelitian ini adalah penelitian kuantitatif dengan mengunakan data sekunder. Teknik pengembilan sampel mengunakan purposive sampling dan berdasarkan kriteria yang telah ditentukan sebelumnya. Dari metode sampling yang diterapkan diperoleh 11 perusahaan asuransi syariah yang terdaftar di Bursa Efek Indonesia (BEI) Periode 2015-2018. Teknik analisis data mengunakan analisis regresi dan analisis jalur dengan mengunakan SPSS 22.

\section{Variabel Penelitian dan Definisi Operasional Variabel}

Penelitian ini menggunakan berbagai variabel untuk melakukan analisis data. Variabel tersebut terdiri dari variabel dependen, variabel independen dan variabel mediasi. Variabel dependen dalam penelitian ini ialah nilai perusahaan, untuk variabel independen adalah maqashid syariah index, dewan komisaris independen dan untuk variabel mediasi ialah profitabilitas.

\section{Nilai Perusahaan}

Nilai perusahaan yang merupakan keadaan yang mengambarkan suatu perusahaan, nilai perusahaan dapat diukur mengunakan rasio price book value (PBV) yang merupakan rasio pasar untuk mengukur kinerja harga pasar saham terhadap nilai bukunya. Semakin tinggi rasio tersebut maka semakin berhasil perusahaan menciptakan nilai bagi pemegang saham. Dengan rumus sebagai berikut:

$$
P B V=\frac{\text { Harga Pasar }}{\text { Book Value }}
$$

\section{Maqashid Syariah Index}

Maqashid Syariah Index merupakan metode yang digunakan untuk menghitung sejauh mana perusahaan mampu menilai kinerja perusahaan dengan menggunakan tiga indikator yaitu tujuan pendidikan Individu, penciptaan keadilan dan pencapaian kesejahteraan yang telah dikembangkan oleh Antonio et al dengan menggunakan metode sekaran. Dengan rumus sebagai berikut:

$$
\mathrm{MSI}=\mathrm{IK}(\mathrm{T} 1)+\mathrm{IK}(\mathrm{T} 2)+\mathrm{IK}(\mathrm{T} 3)
$$

\section{Dewan Komisaris Independen}

Dewan komisaris independen merupakan dewan komisaris yang berasal dari luar perusahaan yang bertujuan untuk melakukan mekanisme pengawasan perusahaan agar berjalan secara efektif sesuai dengan peraturan perundang - undangan. Rasio dewan 
komisaris independen merupakan inti dari tata kelola perusahaan. dirumuskan sebagai berikut:

$D K I=\frac{\text { Jumlah Komisaris Independen }}{\text { Jumlah Anggota Dewan Komisaris }}$

\section{Profitabilitas}

Rasio yang digunakan untuk mengukur kemapuan perusahaan dalam menghasilkan laba dari aktivitas normal bisnisnya, profitabilitas dituntut untuk meningkatkan kinerja perusahaan. banyak jenis-jenis profitabilitas namun yang dipakai pada penelitian adalah rasio return on asset (ROA). dirumuskan sebagai berikut:

$$
\text { ROA }=\frac{\text { Laba Setelah Pajak }}{\text { Total Asset }}
$$

\section{Populasi dan Sampel Penelitian}

Populasi dalam penelitian ini adalah perusahaan asuransi syariah yang terdaftar di Bursa Efek Indonesia (BEI) Periode 2015-2018. Perusahaan asuransi syariah pada Tahun 2015 - 2018 terdapat 84 perusahaan. metode penelitian sampel yang digunakan dalam penelitian adalah metode purpose sampling yaitu pemilihan yang sampel yang dipilih dengan menggunakan kriteria tertentu. Tujuan dari penggunaan kriteria pemlihan sampel ini adalah untuk mempersempit area penelitian yang digunakan, sehingga data yang digunakan dapat ditelaah dengan benar. Adapun kriteria-kriteria yang digunakan dalam memilih sampel penelitian:

1. Perusahaan asuransi syariah yang terdaftar di Bursa Efek Indonesia (BEI) Periode 2015 $-2018$

2. Perusahaan asuransi syariah yang tergolong syariah dan menerbitkan annual report Periode 2015 - 2018 di Bursa Efek Indonesia (BEI) www.idx.co.id

3. Perusahaan asuransi syariah memiliki data lengkap dan menyeluruh terkait variabel maqashid syariah index, dewan komisaris independen, nilai perusahaan dan profitabilitas yang digunakan.

\section{Jenis dan Sumber data}

Jenis data yang digunakan dalam penelitian ini adalah data dokumentasi yang diperoleh dari data laporan (annual repost) mulai 31 Desember 2015 sampai dengan 31 Desember 2018. Sedangkan sumber data yang digunakan adalah data sekunder, yaitu data yang diperoleh secara tidak langsung tetapi melalui penelusuran dari media internet atau website masing - masng perusahaan. sumber lainnya berupa jurnal yang diperlukan dan sumber - sumber lain yang dapat digunakan dalam penelitian ini.

\section{Metode Analisis}

Metode analisis data yang digunakan dalam penelitian ini adalah dengan menggunakan metode kuantitatif. Pendekatan kuantitatif menurut Cooper dan Schindler riset kuantitatif melakukan pengukuran yang lebih akurat terhadap suatu objek, proses dari penelitian ini menggunakan metode kuantitatif yang memuat pengujian dan melakukan verifikasi terhadap kebenaran teori tersebut (Muhajirin dan Maya Panorama. 2017). 
HASIL PENELITIAN DAN PEMBAHASAN

Uji Asumsi Klasik

Uji Multikolinieritas

Tabel 1

Uji Multikolinieritas dengan Tolerance (TOL) dan Variance Inflation Factor (VIF)

Coefficients $^{\mathrm{a}}$

\begin{tabular}{lccccc}
\hline \multicolumn{1}{c}{ Model } & \multicolumn{2}{c}{ Collinearty Statistics } & Model & \multicolumn{2}{c}{ Collinearty Statistics } \\
\hline & \multicolumn{2}{c}{ Persamaan I } & & \multicolumn{2}{c}{ Persamaan II } \\
\hline MSI & Tolerance & VIF & & Tolerance & VIF \\
\hline DKI & 0,997 & 1,003 & MSI & 0,946 & 1,058 \\
\hline & 0,997 & 1,003 & DKI & 0,929 & 1,077 \\
\hline & & & ROA & 0,881 & 1,136 \\
\hline
\end{tabular}

Sumber: Data diolah, 2020

Berdasarkan Tabel 4.5 diatas, diperoleh nilai tolerance dari persamaan I dan persamaan II semua variabel independen $>0,10$ dan nilai VIF dari semua variabel independen $<10,00$, sehingga dapat disimpulkan bahwa tidak terjadi multikolinieritas.

\section{Analisis Substruktural 1}

\section{Tabel 2}

Pengaruh Maqashid Syariah Index, Dewan Komisaris Independen terhadap Profitabilitas

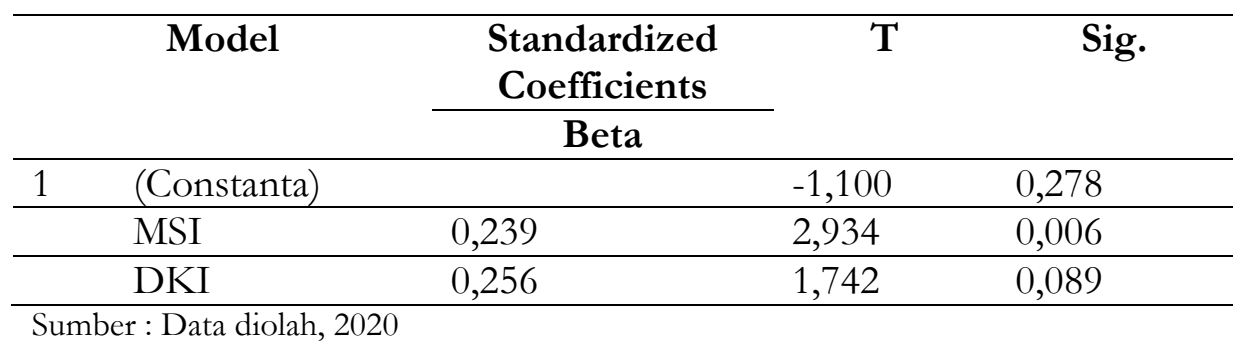

Diperoleh angka t-tabel sebesar 2,01808. Pengaruh maqashid syariah index (MSI) dan Dewan Komisaris Independen (DKI) secara parsial terhadap Profitabilitas (ROA) adalah sebagai berikut :

1. Berdasarkan hasil penelitian, diperoleh angka t-hitung sebesar 2,934 > t-tabel sebesar 2,01808 sehingga Ha diterima dan Ho ditolak. Artinya terdapat pengaruh maqashid syariah index terhadap profitabilitas. Besarnya pengaruh maqashid syariab index terhadap profitabilitas adalah 0,239 atau sebesar 23,9\% dianggab signifikan dengan tingkat signifikansinya sebesar $0,006<0,05$.

2. Berdasarkan hasil perhitungan, diperoleh angka t-hitung sebesar 1,742 < t-tabel 2,01808 sehingga Ha ditolak dan Ho diterima. Artinya tidak terdapat pengaruh dewan komisaris independen terhadap profitabilitas, besarnya pengaruh dewan komisaris independen terhadap profitabilitas adalah 0,256 atau sebesar 25,6\% dianggab tidak signifikan dengan tingkat signifikansinya sebesar $0,089>0,05$. 


\section{Analisis Substruktural 2}

\section{Tabel 3}

Pengaruh maqashid syariah index, dewan komisaris independen, profitabilitas terhadap nilai perusahaan

\begin{tabular}{cccc}
\hline \multirow{2}{*}{ Model } & $\begin{array}{c}\text { Standardized } \\
\text { Coefficients }\end{array}$ & T & Sig. \\
\cline { 2 - 4 } & Beta & & \\
\hline $1 \quad$ (Constanta) & & 5,463 & 0,000 \\
\hline MSI & 0,220 & 1,496 & 0,142 \\
\hline DKI & $-0,496$ & $-6,034$ & 0,000 \\
\hline ROA & 0,758 & 8,983 & 0,000 \\
\hline
\end{tabular}

Sumber : Data diolah, 2020

Diperoleh angka t-tabel sebesar 2,01954. Pengaruh maqashid syariab index (MSI), dewan komisaris independen (DKI), profitabilitas (ROA) terhadap nilai perusahaan adalah sebagai berikut :

1. Berdasarkan hasil perhitungan, diperoleh angka t-hitung sebesar 1,496 < t-tabel 2,01954 sehingga $\mathrm{Ha}$ ditolak dan Ho diterima. Artinya tidak terdapat pengaruh maqashid syariah index terhadap nilai perusahaan, besarnya pengaruh maqashid syariab index terhadap nilai perusahaan adalah 0,220 atau sebesar 22,0\% dianggab tidak signifikan dengan tingkat signifikaninya sebesar $0,142>0,05$.

2. Berdasarkan hasil penelitian, diperoleh angka t-hitung sebesar $-6,034>\mathrm{t}$-tabel sebesar 2,01954 sehingga Ha diterima dan Ho ditolak. Artinya terdapat pengaruh dewan komisaris independen terhadap nilai perusahaan. Besarnya pengaruh dewan komisaris independen terhadap nilai perusahaan adalah $-0,496$ atau sebesar $-4,96 \%$ dianggab signifikan dengan tingkat signifikansinya sebesar $0,000<0,05$.

3. Berdasarkan hasil penelitian, diperoleh angka t-hitung sebesar 8,983 > t-tabel sebesar 2,01954 sehingga Ha diterima dan Ho ditolak. Artinya terdapat pengaruh profitabilitas terhadap nilai perusahaan. Besarnya pengaruh profitabilitas terhadap nilai perusahaan adalah 0,758 atau sebesar $75,8 \%$ dianggab signifikan dengan tingkat signifikansinya sebesar $0,000<0,05$.

\section{Pengujian Variabel Mediasi dengan Menggunakan Path Analysis}

\section{Strategi Casual Step}

Pengaruh maqashid syariah index terhadap nilai perusahaan dengan dimediasi profitabilitas)

Berikut ini merupakan kerangka uji mediasi: 


\section{Gambar 3}

\section{Uji Mediasi I}

(c) : 37,1803

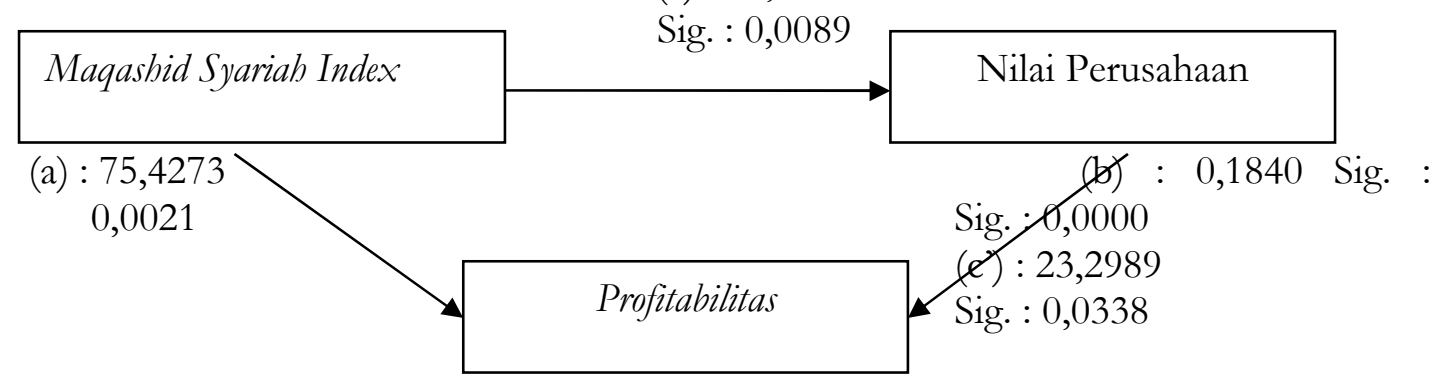

Keterangan $: \mathrm{Y}=\beta$ Maqashid Syariah Index $+\beta$ Profitabilitas $+\mathrm{e}$

Hasil analisis ditemukan bukti bahwa maqashid syariah index signifikansi terhadap profitabilitas dengan nilai signifikan 0,0021 $<0,05$ dan koefisien regresi (a) $=75,4273$ dan maqashid syariah index signifikan terhadap nilai perusahaan dengan nilai signifikan $0,0089<$ 0,05 dan koefisien regresi $(\mathrm{c})=37,1803$. Terakhir hasil analisis ditemukan ditemukan bahwa profitabilitas signifikan terhadap nilai perusahaan setelah mengontrol maqashid syariah index dengan nilai signifikan $0,0000<0,05$ dan koefisien $(b)=0,1840$. Selanjutnya ditemukan pula direct effect c' sebesar 0,0338 lebih besar dari $\mathrm{c}=0,0089$. Pengaruh variabel bebas maqashid syariah index terhadap variabel terikat nilai perusahaan dengan signifikansi $0,0089<$ 0,05. Setelah mengontrol variabel mediasi profitabilitas. Dengan demikian dapat disimpulkan bahwa ini termasuk dalam kategori Partial Mediation artinya variabel independen maqashid syariah index (X1) mampu mempengaruhi secara langsung variabel dependen nilai perusahaan $(\mathrm{Y})$ atau tanpa melibatkan variabel mediasi profitabilitas $(\mathrm{M})$.

\section{Pengaruh Dewan Komisaris Independen terhadap Nilai Perusahaan dengan Profitabilitas sebagai Variabel Mediasi} berikut ini:

Berikut ini merupakan kerangka uji mediasi seperti yang ditunjukkan pada Gambar

\section{Gambar 4}

\section{Uji Mediasi II}

(c) : $-149,2833$

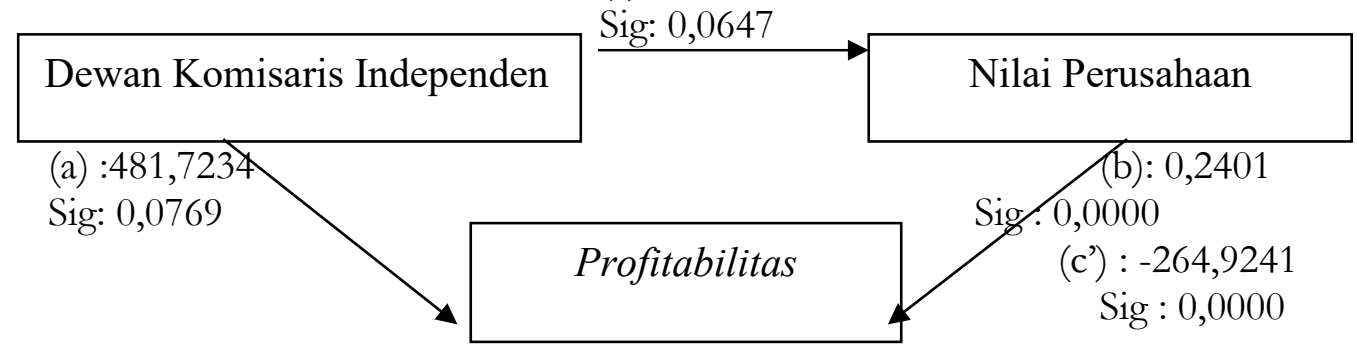

Hasil analisis ditemukan bukti bahwa dewan komisaris independen (X2) tidak signifikansi terhadap profitabilitas dengan nilai signifikan $0,0796>0,05$ dan koefisien regresi (a) = 481.7234 dan dewan komisaris independen (X2) tidak signifikan terhadap nilai perusahaan dengan nilai signifikan 0,0647 > 0,05 dan koefisien regresi nya (c) -149,2833. 
Terakhir ditemukan bahwa profitabilitas $(\mathrm{M})$ signifikan terhadap nilai perusahaan $(\mathrm{Y})$ setelah mengontrol dewan komisaris independen (X2) dengan nilai signifikan 0,0000 $<0,005$ dan koefisien 0,2401, selanjutnya ditemukan c' sebesar 0,0000 lebih kecil dari 0,0647. Pengaruh variabel bebas dewan komisaris independen (X2) terhadap variabel terikat nilai perusahaan (Y) dengan signifikan $0,0647>0,05$ setelah mengontrol variabel mediasi profitabilitas $(\mathrm{M})$ dengan demikian dapat disimpulkan model ini termasuk kartegori unmediated artinya variabel independen dewan komisaris independen (X1) mampu mempengaruhi secara langsung variabel nilai perusahaan $(\mathrm{Y})$ tanpa melibatkan variabel mediator profitabilitas $(\mathrm{M})$.

\section{PEMBAHASAN}

\section{Pengaruh Maqashid Syariah Index terhadap Profitabilitas}

Berdasarkan hasil penelitian statistik dalam menggunakan IBM SPSS Statisties 22 secara parsial pengaruh maqashid syariah index terhadap profitabilitas diperoleh angka t-hitung sebesar 2,934 > t-tabel sebesar 2,01954 sehingga Ha diterima dan Ho ditolak. Artinya terdapat pengaruh maqashid syariah index terhadap profitabilitas. Besarnya pengaruh maqashid syariah index terhadap profitabilitas adalah 0,239 atau sebesar 23,9\% dianggab signifikan dengan tingkat signifikansinya sebesar $0,006<0,05$. Sehingga hipotesis pertama (H1) diterima. Hal ini menunjukkan bahwa besarnya peningkatan maqashid syariah index maka akan dipengaruhi oleh profitabilitas yang diperoleh dari perusahaan.

Hal ini sejalan dengan konsep teory sinyal bahwa perusahaan dengan tingkat maqashid syariah index yang tinggi menjadi sinyal yang baik dalam memperoleh respon dari calon investor yang menunjukkan bahwa kondisi perusahaan berada dalam kondisi profitabilitas. Maqashid syariah index yang memiliki 3 tujuan menciptakan kesejahteraan bagi masyarakat luas yaitu pendidikan individu merupakan tujuan untuk memberikan pendidikan dan kemampuan serta menanamkan nilai-nilai individu untuk perkembangan spiritual bagi masyarakat luas dan karyawan, penciptaan keadilan merupakan tujuan dimana perusahaan menjalankan kegiataan dan aktivitas perusahaan bebas dari elemen-elemen negatif yang dapat menciptakan ketidakadilan seperti kecurangan, sedangkan pencapaian kesejahteraan merupakan tujuan tujuan dimana perusahaan harus membuat prioritas mengenai aktifitas bisnis yang memberikan manfaat lebih besar bagi masyarakat.

\section{Pengaruh Dewan Komisaris Independen terhadap Profitabilitas}

Berdasarkan hasil penelitian statistik dalam menggunakan IBM SPSS Statisties 22 secara parsial pengaruh dewan komisaris independen terhadap profitabilitas diperoleh angka t-hitung sebesar 1,742 < t-tabel 2,01808 sehingga Ha ditolak dan Ho diterima. Artinya tidak terdapat pengaruh dewan komisaris independen terhadap profitabilitas, besarnya pengaruh dewan komisaris independen terhadap profitabilitas adalah 0,256 atau sebesar $25,6 \%$ dianggab tidak signifikan dengan tingkat signifikansinya sebesar 0,089 > 0,05 . Sehingga hipotesis ke dua (H2) ditolak.

Hal ini sejalan dengan theory agency yang menjelaskan bahwa pengawasan yang tepat dapat mengurangi konflik kepentingan antara agent dan principal. Adanya dewan komisaris independen akan meningkatkan kualitas fungsi pengawasan dalam perusahaan. menurut KNKG jumlah komisaris independen harus dapat menjamin agar mekanisme pengawasan berjalan secara efektif dan sesuai dengan peraturan perundang-undangan. 


\section{Pengaruh Maqashid Syariah Index terhadap Nilai Perusahaan}

Berdasarkan hasil penelitian statistik dengan menggunakan IBM SPSS Statisties 22 secara parsial pengaruh maqashid syariah index terhadap nilai perusahaan diperoleh angka thitung sebesar 1,496 < t-tabel 2,01808 sehingga Ha ditolak dan Ho diterima. Artinya tidak terjadi pengaruh maqashid syariah index terhadap nilai perusahaan, besarnya pengaruh maqashid syariah index terhadap nilai perusahaan adalah 0,220 atau sebesar 22,0\% dianggab tidak signifikan dengan tingkat signifikaninya sebesar 0,142>0,05 sehingga hipotesis ke tiga (H3) ditolak.

Hal ini tidak sejalan dengan teori sinyal yang menyatakan bahwa adanya sinyal peningkatan maqashid syariah index dapat menentukan nilai perusahaan juga meningkat namun pada hasil penelitian ini menunjukan bahwa belum tercapainya maqashid syariah index pada perusahaan asuransi yang berarti investor belum dapat menjadikan maqashid syariah index sebagai ukuran penilaian perusahaan karena perusahaan asuransi belum secara keseluruhan menjalankan maqashid syariah index secara baik dan perlu adanya peningkatan dalam pelaksanaan tujuan syariah serta adanya faktor lain yang berpengaruh terhadap nilai perusahaan.

\section{Pengaruh Dewan Komisaris Independen terhadap Nilai Perusahaan}

Berdasarkan hasil penelitian statistik dengan menggunakan IBM SPSS Statistics 22 secara parsial pengaruh dewan komisaris independen terhadap nilai perusahaan diperoleh angka t-hitung sebesar -6,034 > t-tabel sebesar - 2,01954 sehingga Ha diterima dan Ho ditolak. Artinya terdapat pengaruh dewan komisaris independen terhadap nilai perusahaan. Besarnya pengaruh dewan komisaris independen terhadap nilai perusahaan adalah -0,496 atau sebesar - 4,96\% dianggab signifikan dengan tingkat signifikansinya sebesar 0,000< 0,05. Sehingga hipotesis ketiga diterima (H3).

Hal ini sejalan teory agency yang menyatakan bahwa dengan adanya dewan komisaris independen maka pengawasan pada perusahaan akan terlaksana dengan baik sehingga meminimalisir tindak kecurangan (agency conflict) yang dilakukan manajemen dalam pelaporan keuangan perusahaan.

\section{Pengaruh Profitabilitas terhadap Nilai Perusahaan}

Berdasarkan hasil penelitian statistik dengan menggunakan IBM SPSS Statistics 22 secara parsial pengaruh profitabilitas terhadap nilai perusahaan diperoleh angka t-hitung sebesar sebesar 8,983 > t-tabel sebesar 2,01954 sehingga Ha diterima dan Ho ditolak. Artinya terdapat pengaruh profitabilitas terhadap nilai perusahaan. Besarnya pengaruh profitabilitas terhadap nilai perusahaan adalah 0,758 atau sebesar 75,8 \% dianggab signifikan dengan tingkat signifikansinya sebesar $0,000<0,05$. Sehingga hipotesis kelima (H5) diterima.

Sesuai dengan perspektif teori sinyal yang menjelaskan bahwa peningkatan profitabilitas yang tercantum dalam laporan keuangan merupakan upaya dalam memberikan sinyal kepada investor berkaitan dengan kinerja perusahaan dan pertumbuhan prospek usaha di masa mendatang. Upaya tersebut dapat membangun segmen positif dari investor sehingga berpengaruh terhadap kenaikan harga saham di pasar modal. Peningkatan harga saham dapat meningkatkan nilai perusahaan di mata investor. 


\section{Pengaruh Maqashid Syariah Index terhadap Nilai Perusahaan melalui Profitabilitas}

Berdasarkan hasil penelitian statistik dengan menggunakan IBM SPSS Statistics 23 hasil analisis ditemukan bukti bahwa profitabilitas signifikan terhadap nilai perusahaan setelah mengontrol maqashid syariah index dengan nilai signifikan 0,0000 $<0,05$ dan koefisien $(b)=0,1840$. Selanjutnya ditemukan pula direct effect c' sebesar 0,0338 lebih besar dari $\mathrm{c}=0,0089$. Pengaruh variabel bebas maqashid syariab index terhadap variabel terikat nilai perusahaan dengan signifikansi $0,0089<0,05$. Setelah mengontrol variabel mediasi profitabilitas, sehingga hipotesis keenam (H6) diterima. Hal ini sejalan dengan teori sinyal, semakin tinggi maqashid syariah index dan profitabilitas suatu perusahaan akan menjadi informasi yang baik bagi perusahaan sehingga dapat direspon positif oleh investor dan akan berpengaruh terhadap nilai perusahaan.

\section{Pengaruh Dewan Komisaris Independen terhadap Nilai Perusahaan melalui Profitabilitas}

Berdasarkan hasil penelitian statistika dengan menggunakan IBM SPSS Statistics 22 hasil analisis ditemukan bahwa profitabilitas (M) signifikan terhadap nilai perusahaan (Y) setelah mengontrol dewan komisaris independen (X2) dengan nilai signifikan $0,0000<$ 0,005 dan koefisien 0,2401, selanjutnya ditemukan c' sebesar 0,0000 lebih kecil dari 0,0647. Pengaruh variabel bebas dewan komisaris independen (X2) terhadap variabel terikat nilai perusahaan $(\mathrm{Y})$ dengan signifikan $0,0647>0,05$ setelah mengontrol variabel mediasi profitabilitas $(\mathrm{M})$, sehingga hipotesis ketujuh ( $\mathrm{H} 7)$ ditolak (unmediated) yang artinya variabel independen dewan komisaris independen (X1) mampu mempengaruhi secara langsung variabel nilai perusahaan $(\mathrm{Y})$ tanpa melibatkan variabel mediator profitabilitas $(\mathrm{M})$.

Hal ini tidak sejalan dengan teory agency yang menjelaskan bahwa pengawasan yang tepat dapat mengurangi konflik kepentingan antara agency dan principal, dimana nilai korelasi terdapat hubungan yang menunjukkan bahwa semakin tinggi tingkat rasio dewan komisaris independen maka dapat mengurangi konflik perusahan yang berdampak pada profitabilitas dengan peningkatan nilai perusahaan.

\section{KESIMPULAN}

Penelitian ini menemukan bahwa maqashid syariah index berpengaruh terhadap profitabilitas, artinya peningkatan maqashid syariah index secara langsung akan berdampak pada profitabilitas perusahaan. Dewan komisaris independen tidak berpengaruh terhadap profitabilitas, artinya sedikitnya proporsi dewan komisaris independen tidak berpengaruh terhadap profitabilitas perusahaan. Maqashid syariah index tidak berpengaruh terhadap nilai perusahaan, artinya dengan ada atau tidaknya maqashid syariah index tidak berpengaruh terhadap nilai perusahaan. Dewan komisaris independen berpengaruh terhadap nilai perusahaan, artinya dengan adanya dewan komisaris independen akan mengurangi kecurangan pelaporan keuangan yang berpengaruh terhadap nilai perusahaan.

Profitabilitas berpengaruh terhadap nilai perusahaan, artinya peningkatan profitabilitas secara langsung akan berdampak pada nilai perusahaan. Profitabilitas memediasi sebagian (partial mediation) pengaruh maqashid syariah index terhadap nilai perusahaan. Ini berarti bahwa variabel indepeden maqashid syariah index mampu mempengaruhi secara langsung variabel dependen dengan atau tanpa variabel mediasi profitabilitas. Profitabilitas tidak memediasi (unmediated) dewan komisaris independen terhadap nilai perusahaan, artinya variabel independen dewan komisaris independen 
mampu mempengaruhi secara langsung variabel dependen nilai perusahaan tanpa melibatkan variabel mediator profitabilitas.

\section{Keterbatasan}

Adapun keterbatasan dalam penelitian ini adalah objek pada penelitian ini masih terbatas pada perusahaan asuransi syariah yang terdaftar di BEI (Bursa Efek Indonesia) yang menerbitkan rasio maqashid syariah index dan jurnal mengenai maqashid syariah index. Diharapkan penelitian selanjutnya dapat menggunakan periode yang lebih panjang agar tingkat akurat penelitian lebih tinggi.

\section{DAFTAR PUSTAKA}

[1]. Aisah, Novilia. 2016. Analisis Kinerja Kenangan Perbankan Syariah di Indonesia dengan Pendekatan Sharia Maqashid Index. Jawa Timur :Universitas Jember,.

[2]. Akbar, Dinnul Alfian dan Rika Lidyah,.2017. Manajemen Kenangan. Palembang : Noerfikri,.

[3]. Ayu, Dea Putri. A.A. Gede Suarjaya. 2017. Pengarub Profitabilitas terhadap Nilai Perusahaan dengan Corporate Social Responsibilty sebagai Variabel Mediasi pada Perusahaan Pertambangan. Universitas Udayana Bali : Skripsi,.

[4]. Brigham \& Houstom. 2006. Fundamentals Of Financials Managemen (Dasar - dasar Manajemen Keuangan ). Jakarta : Salemba,.

[5]. Damayanti, Alfina Rossa. 2018. Pengarub Profitabilitas dan Maqashid Syariab Index terbadap Nilai Perusahaan melalui Islamic Social Reporting sebagai variabel moderating (Studi Kasus Bank Umum Syariah tahun 2012 - 2016). Universitas Islam Negeri Maulana Malik Ibrahim Malang : Skripsi,.

[6]. Desiana, Lidia. 2018. Analisis Laporan Keuangan (Teori dan Pemahaman Materi). Palembang : Noerfikri.

[7]. Dewi, Laurensia Chintia. \& Yeterina Widi Nugrahanti. 2014. Pengarub Struktur Kepemilikan dan Dewan Komisaris Independen terbadap Nilai Perusabaan (Studi pada

[8]. Dewi, Sandra. 2018. Analisis Pengaruh Ukuran Perusahaan dan Kinerja Maqashid Syariah Index terhadap Nilai Perusabaan (Studi pada Bank Umum Syariab tahun 2012 - 2016). Universitas Islam Negeri Maulana Malik Ibrahim Malang : Jurusan Perbankan Syariah Fakultas Ekonomi,

[9]. Fahmi, Irham. 2015. Analisis Laporan Kenangan, cetakan Ke-5. Bandung: Alfabeta,.

[10].Harjito, Agus dan Martono. 2018. Manajemen Kenangan Edisi ke-2. Yogjakarta: Ekonosia,.

[11].Irianto, Agus . Statistika Konsep Dasar, Aplikasi dan Pengembangan, Edisi Keempat. Jakarta : Kencana. ,

[12].Kasmir. 2015. Analisis Laporan Kenangan. Jakarta : PT Raja Grafindo Persada.

[13].Maya, Panorama dan Muhajirin. 2017. Pendekatan Praktis Metode Penilaian Kualitatif dan Kuantitatif. Idea Press: Yogyakarta,

[14].Priyanto, Dwi. 2010. Paham Analisis Statistika Data dengan SPSS. Yogyakarta : Mediakom,

[15].Safietrie, Dian. 2017. Pengaruh Dewan Komisaris Independen terbadap Profitabilitas Bank Syariah dengan Non Performing Financing (NPF) sebagai variabel intervening. IAIN Salatiga,.

[16].Sanrego, Antonio dan Taufiq. 2012. An Analysis of Islamic Banking Performance Maqashid Index Implementation in Indonesia and Jordania. Journal of Islamic Finance,. 
[17].Widarjono, Agus. 2010. Analisis Statistika Multivariat Terapan. Yogyakarta : Unit Penerbitan dan Percetakan Sekolah Tinggi Ilmu Manajemen YKPN,

[18].www.knkg-indonesia.org. Pedoman .2011. GCG Pialang Asuransi Reasuransi,. 